\title{
Scenario Analysis of the Intellectual Capital Development of the Region in Postcovid Economics Based on Financial Assets
}

\author{
Gataullin Iskander Ilgizovich ${ }^{1} \&$ L. M. Zabirova ${ }^{1}$ \\ ${ }^{1}$ Department of Production Economics, Institute of Management, Economics and Finance, Kazan Federal University, \\ Kazan, Republic of Tatarstan, Russia \\ Correspondence: Gataullin Iskander Ilgizovich, Department of Production Economics, Institute of Management, \\ Economics and Finance, Kazan Federal University, Kazan, Republic of Tatarstan, Russia. Tel: 7-987-221-5144.
}

Received: August 30, 2020

Accepted: October 5, 2020

Online Published: November 30, 2020

doi:10.5430/ijfr.v11n6p129

URL: https://doi.org/10.5430/ijfr.v11n6p129

\begin{abstract}
The article presents the main trends and factors involved in developing intellectual capital in the region during and after the pandemic of Covid-19 based on financial assets, which are of strategic importance both for the state and for international development. The authors provide benefits and drawbacks to the growth of the situation in the context of the main elements of the region's intellectual capital. These factors consist of Innovative activities in the region (Intellectual Property Market, Innovative infrastructure of the region, Innovative activities of organizations) and Human Resources (Labor Market, Higher, and Continuing Professional Education System). A pessimistic scenario involves that the state and the economic system could not cope with a negative trend for various reasons. On the other hand, an optimistic scenario implies that the state and economic entities can see the trend as an opportunity and apprehend it to stabilize the region's economic situation and further surmount the crisis.
\end{abstract}

Keywords: intellectual capital of the region, intellectual resources, scenario approach, optimistic forecast, pessimistic forecast, postcovid economics

\section{Introduction}

The coronavirus pandemic (COVID-19) has become a serious social and economic shock and challenge that has affected almost all countries of the world. According to the European Center for Disease Prevention and Control [European Centre for Disease Prevention and Control], at the end of June 2020, more than 10302000 cases of COVID-19 diseases were recorded, of which 505518 were fatal. According to realistic estimates, it is worth counting on 6-12 months, rather severe restrictions, the existing serious economic and social consequences.

During the pandemic, a particularly severe blow fell on the world economy. Quarantines, self-isolation regimes are, as a rule, the shutdowns of most businesses and a corresponding decrease in the incomes of their participants, which means a drop in consumption and savings. Obviously, the first causes a drop in income for most businesses that are part of the value chain; a decrease in consumption leads to a drop in the value of long-term and financial assets. According to Bloomberg, citing analysts at JPMorgan Chase \& Co, the coronavirus pandemic will rob the world economy of $\$ 5.5$ trillion in the next two years [Bloomberg estimates the loss of the global economy]. At the same time, the forecast of the World Trade Organization (WTO) implies a drop in world trade in 2020 by more than $30 \%$ [Trade set to plunge as COVID-19 pandemic upends global economy]. Experts at the World Economic Forum [Challenges and Opportunities in the Post-COVID-19 World] believe that major changes will occur in the areas of international exchange not only of goods and services, but also of people and ideas. In recent years, there have been movements of huge flows of migrants, businessmen, students, tourists. Due to the closure of borders in many countries, this flow has significantly decreased, and obviously, this trend will continue after the end of the pandemic due to the wariness of both people themselves and states (Leontyeva, and Orlova, 2015). The globalization of the global economy has led to the creation of complex international supply chains. During a pandemic, these supply chains begin to collapse, resulting in tremendous delays and losses for many businesses, both in trade and in manufacturing. At the same time, in the services sector, there is an increasing trend towards the digitalization of most services, which lead to tremendous growth in the segment of telecommunications and online commerce and entertainment companies, that is, to serious structural changes in the economy and employment. One of the most positive trends has emerged in the field of exchange of knowledge and ideas, due to the accelerated international cooperation of scientists in the search for antiviral vaccines and drugs 
(Leliaert et al., 2003). With a high probability, this style of work can take root and spread to other areas of knowledge.

Based on this, it can be assumed that new knowledge and high-tech developments may be the driver of overcoming the crisis and restoring the international economy. The experience of the crisis periods of the beginning of the 21st century demonstrated the growing role of intellectual capital, the development of technology in adapting to new conditions and overcoming crises. Thus, the SARS pandemic of 2002-2004 became a catalyst for the rapid growth of e-commerce, which at that time was only taking its first steps. Ali Baba has taken it to the forefront of retail e-commerce in Asia. The 2008 financial crisis also led to a number of devastating side effects caused by the decline in consumption. Airbnb and Uber have grown in popularity in the west as subprime lending crises meant lower savings and incomes, forcing people to share assets - free rooms and car trips to cover the deficit. In the new economic, technological and social realities, it is the intellectual capital of the country and regions that is one of the leading factors affecting the processes of restoration of the regional economy in the post-crisis period (Chen et al., 2004). The purpose of this study is to study the main trends and factors in the development of intellectual capital in the region during and after a pandemic, which are of strategic importance.

\section{Methods}

Intellectual capital is a set of interconnected intellectual resources, the efficiency of use of which leads to an increase in the competitiveness of a country, region, and enterprise. And intellectual resources are one of the types of economic resources that includes the results of creative and intellectual work of people, as well as organizational knowledge inherent in the subject, which can be used for a long time for the production of goods and their commercialization (Gataullin, 2018).

In our opinion, it is at the regional level that the most significant changes are taking place, since here there is a combination of efforts by the state to support the labor market, innovative infrastructure, strategically important industries and the activities of specific organizations.

According to the author's approach, the structure of the region's intellectual capital consists of 2 main components, shown in Figure 1.

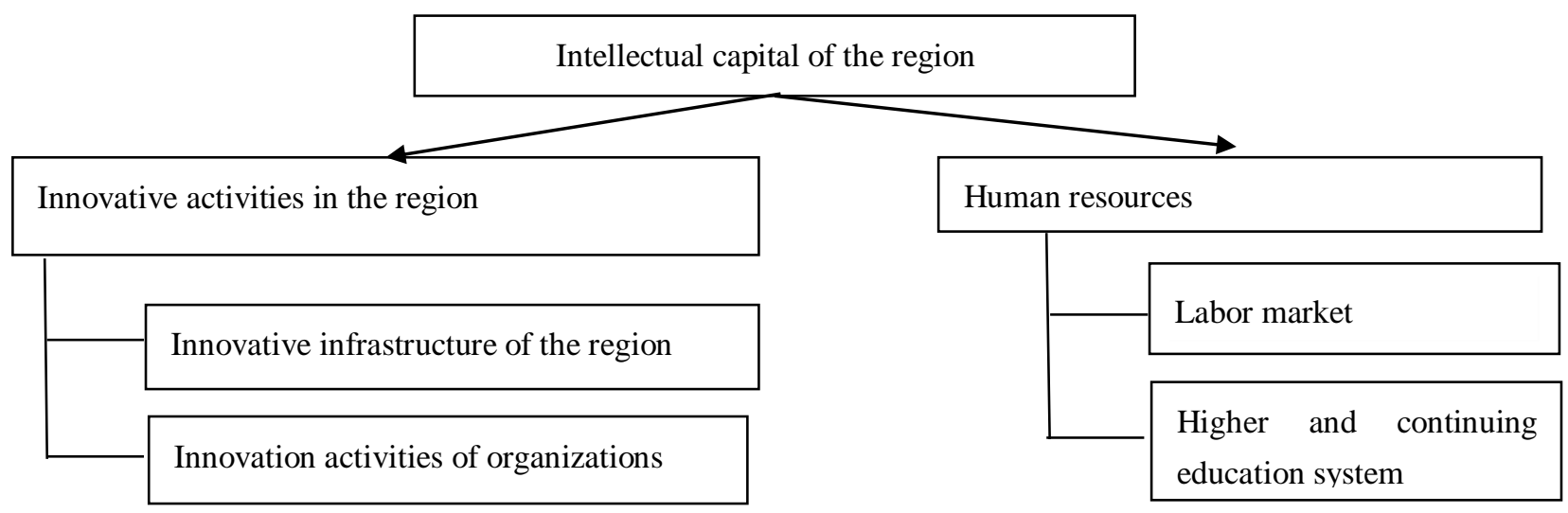

Figure 1. Region's intellectual capital structure

Human resources, which are the working-age population, with their skills, knowledge and skills, create a gross regional product.

Innovative activities of the region - a set of scientific, organizational, technological, financial and commercial measures at the regional level, aimed at the commercialization of the knowledge accumulated and generated in the region. This group includes the following 3 intellectual resources:

In preparing this article, we used a scenario approach to determine the pessimistic and optimistic development of each of the elements of intellectual capital. In our understanding, a scenario is a sequential description of alternative hypothetically possible options for the development of events in the future, which reflects different points of view on the past, present and future, and which can also serve as a basis for planning actions (Van Notten, 2006). 
In the interpretation of the famous researcher in the field of studying the future using the scenario approach Peter Schwartz [The economy of wartime], the following stages can be distinguished in a scenario study:

1. The preparatory phase:

A. Definition of the focus of the study;

B. An indication of the key factors of the microenvironment (internal characteristics);

B. Determination of the driving forces of the macroenvironment (external factors);

D. The choice of "logic" / method of constructing scenarios based on prepared data.

2. Specification of scenarios.

3. Consideration of the consequences of the constructed scenarios.

The main results of the preparatory stage of the scenario analysis are presented in Table 1.

Table 1 . The content of the preparatory stage of the scenario analysis of the development of intellectual capital

\begin{tabular}{|c|c|}
\hline Stage Name Stage Content & Stage Name Stage Content \\
\hline $\begin{array}{l}\text { A. Defining the focus of } \\
\text { the study. }\end{array}$ & $\begin{array}{l}\text { Development of elements of intellectual capital under the influence of negative } \\
\text { trends related to the COVID-19 pandemic. }\end{array}$ \\
\hline $\begin{array}{l}\text { B. Indication of the critical } \\
\text { factors of the } \\
\text { microenvironment } \\
\text { (internal characteristics) }\end{array}$ & $\begin{array}{l}\text { - The state of human resources in the region (health, education, employment, } \\
\text { mobility, socio-demographic structure. } \\
\text { - The economic condition of the domestic market for goods and services in the } \\
\text { region; } \\
\text { - Regional policy of supporting the population and economic entities of the region }\end{array}$ \\
\hline $\begin{array}{l}\text { B. Determination of the } \\
\text { driving forces of the } \\
\text { macroenvironment } \\
\text { (external factors) }\end{array}$ & $\begin{array}{l}\text { - The economic condition of external interregional and international markets for } \\
\text { goods and services in the region; } \\
\text { - State and international economic and social policies; } \\
\text { - The spread of the disease COVID -19 }\end{array}$ \\
\hline $\begin{array}{l}\text { D. The choice of "logic" } \\
\text { method of constructing }\end{array}$ & $\begin{array}{l}\text { Weighing up each of the above factors, a particular trend is formed for each element } \\
\text { of intellectual capital. Based on this trend, two scenarios are built: } \\
\text { - A pessimistic scenario in which the state and the economic system could not cope } \\
\text { with a negative trend for a combination of reasons; } \\
\text { - An optimistic scenario in which the state and economic entities were able to see the } \\
\text { trend as an opportunity and realize it to stabilize the economic situation in the region } \\
\text { and further overcome the crisis }\end{array}$ \\
\hline
\end{tabular}

\section{Results and Discussion}

\subsection{Innovative Infrastructure}

This group of resources may include both objects of the state innovation infrastructure and commercial organizations that provide services to provide access to innovation infrastructure.

Pessimistic forecast.

A. Due to the fact that most enterprises suffered significant losses, and some went bankrupt, transnational companies and state corporations are beginning to play an increasingly important role. According to the professor of the RANEPA, Korishchenko K. [A New Balance: How the World Economy Will Change After a Pandemic], along with Gazprom and Sberbank, the largest company in Russia could be a universal marketplace (conditional Government services) that can concentrate most of the vital services and timely provide the population with the essential ones - first with services, and then with goods. It follows that further monopolization will take place, the share of small venture capital businesses, which without the lobby from state corporations, will not be able to withstand competition in the market, will lead to a decrease in demand for innovative supporting institutions, such as innovative incubators and facilitators. 
B. Most of the resources of the state and its regions will be spent on coping with the consequences of the pandemic. Therefore, the need to support the economy and the population will lead to a significant budget reduction in terms of organizing and developing innovative institutions in the regions. This trend will intensify due to a significant slowdown in consideration of projects that are not aimed at solving priority problems: combating the pandemic, mobilizing the healthcare system, social security.

Optimistic forecast.

A. Although the majority of sectors of the economy showed a significant decline, there are still several sectors that, due to the epidemic, are making a giant leap forward. First of all, it is pharmacology and medicine, into which huge state subsidies and international grants pour in during the period of the fight against the epidemic. The second largest segment was the online telecommunications and communications resources: due to the current situation, most people were forced to use online technologies and resources and many were already accustomed to they understood that they are comfortable, so this segment will undoubtedly also grow after the pandemic. The third most important segment was robotics. According to IDC analysts [IDC says China's ICT Market Faces Both Opportunities and Challenges amid the COVID-19 Outbreak], we will soon see a significant increase in demand for industrial robots that are able to control supply management systems. This means that private and public investors will need to create the infrastructure for the growth of economic ecosystems for these industries.

B. Another trend suggests a positive impact of the import substitution strategy, which will entail the creation of new enterprises and logistics solutions. First of all, this is due to the fact that current problems in cross-border trade are stimulating businesses to find alternatives for components of their production processes among domestic producers. Thus, this trend suggests that the region in which investments will be directed to the development of self-sufficient production complexes will need to develop not only transport, but also innovative infrastructure in the region.

\subsection{Innovation Activities of Organizations}

This element of the region's intellectual capital includes the results of innovative activities of organizations located in the region in the development and implementation of new technologies and products.

Pessimistic forecast.

A. According to WHO experts [WHO warns of threat of "destructive" second wave of coronavirus], the world expects a second wave of the epidemic soon enough after the first. In such circumstances, stability will be the focus of attention, primarily in meeting the basic needs of the population. Thus, most of the state budget and reserve funds will be aimed at providing social guarantees and supporting the population. This will limit the state's ability to support the innovative activity of enterprises (except for strategically important industries). The enterprises themselves will first of all direct their financial resources to ensure a stabilization strategy, ensuring cost reduction and optimizing the number of personnel and departments related to human resources, research and development.

B. There is an increasing risk of budgetary resources being cut to support the innovative activity of enterprises in the real sector of the economy and research and development that are not priority and strategically important.

Optimistic forecast.

A. The trend associated with the rise of the pharmaceutical industry, medicine, robotics and telecommunications also positively affects the development of innovative activities of the enterprise. This means increasing interest in investing in these types of activities among private investors, which leads to the modernization and creation of new technological high-tech solutions. This will lead to positive structural changes in the country's economy in favor of the branches of the knowledge economy.

B. The tendency to ensure the self-sufficiency of the economy in strategically important areas has been noted in Russian practice over the past decade. This is expressed not only in import substitution programs, but also in the development of R\&D that creates the basis of product and process innovations in order to ensure economic security. This will require large public and private investments in the innovative activity of enterprises of strategically important sectors of the economy.

No less important changes will occur with another element of intellectual capital - human capital.

\subsection{Labor Market}

Pessimistic forecast.

A. WHO estimates that up to 300 million people can lose their jobs due to the coronavirus pandemic. [Challenges and Opportunities in the Post-COVID-19 World] There are several reasons for this. Firstly, there is a rapid ruin of small 
business, and massive reductions in the number of employees in medium and large businesses. Secondly, the situation is aggravated by the growing tendency to automate many business processes. Such a huge release of people can lead to social unrest, and most importantly - a significant drop in the solvent demand of the population, which leads to an increase in poverty and increases the risks of socio-political conflicts.

B. A further increase in shadow employment is expected, as well as increased migration of skilled workers of working age to the labor-surplus regions of the country. This threatens the prospects for the development of this part of human resources, and also exacerbates the social problems of Russian megacities.

Optimistic forecast.

A. Due to the fact that many business processes have gone online, there is an increase in the trend towards the development of a "gig" economy, which is based on the work of freelance workers or the "economy of short-term contracts", where temporary work with a flexible schedule predominates. One of the main advantages for employees is a significant increase in opportunities for self-employment, searching for work in the online space: for example, more and more highly skilled specialists who live in the outback and cannot fully realize their labor potential will be able to work remotely in large and medium-sized companies that provide it learning and development opportunity.

B. Creation of new modern jobs in high-tech activities, in the sectors of the knowledge economy, and public services. Also, new jobs can be created in the construction of infrastructure and industrial facilities.

\subsection{Higher and Continuing Education System}

Pessimistic forecast

A decrease in the training of personnel with higher education at the expense of the budget, limited opportunities for families to invest in teaching children at universities will lead to a reduction in the number of faculty members of higher educational institutions, which are an important component of the intellectual capital of the region. The system of additional professional education may be reduced due to the strategy of reducing the costs of organizations-customers for advanced training and retraining of personnel. At the same time, organizations are expanding training through activities and e-learning, which requires significantly lower financial costs.

Optimistic forecast

A. In connection with the pandemic, all educational institutions switched to distance learning, and online educational courses began to gain popularity in corporate training. This is due to the fact that now many types of activities are switching to the remote work mode, which, as a rule, increases the requirements for staff qualifications. Such a significant expansion of the online learning market increases competition in this area, which will lead to the need to increase the quality of educational content in order to become competitive. In a similar situation, many universities, accustomed to working in the traditional format, will have to adapt and begin to process programs for conversion to a remote format. In these circumstances, they have to compete with existing online education companies. Such competition can benefit the quality of work of both private companies engaged in online education and universities.

B. The trend to accelerate the development of medicine, pharmaceuticals, robotics, and telecommunications will require not only the development of new technologies but also the advanced training of workers in this field, in connection with such a request, private and state educational organizations will be forced to significantly update and improve the quality of educational programs and resources. In addition, the state itself needs to adapt to the changes associated with the transition to industry 4.0. For which it is advisable to subsidize and organize grant systems and other government support measures to create more effective training systems (including distance learning).

B. The expansion of the boundaries of international cooperation can have a positive effect on the vocational education system, in view of the fact that it opens up opportunities for wider international cooperation between universities and higher and additional professional education.

\section{Summary}

More briefly and summarized the results of the study in the context of the region's intellectual capital resources are presented in Table 2. It shows the positive and negative consequences and opportunities offered by new trends in socio-economic development during and after the pandemic. 
Table 2. The influence of the socio-economic development in the post-pandemic period on the region's intellectual capital and the environment of innovation

\begin{tabular}{|c|c|c|c|}
\hline Trends & $\begin{array}{l}\text { Intellectual } \\
\text { Resources }\end{array}$ & $\begin{array}{l}\text { Type } \\
\text { Change }\end{array}$ & Problem / Opportunity Description \\
\hline \multirow[t]{2}{*}{$\begin{array}{l}\text { Moving a business into } \\
\text { the online space }\end{array}$} & $\begin{array}{l}\text { The system of higher } \\
\text { and continuing } \\
\text { professional education }\end{array}$ & $\begin{array}{l}\text { positive. } \\
\text { education }\end{array}$ & $\begin{array}{l}\text { Expansion of the segment of online education, increasing } \\
\text { requirements for the quality of education, access to }\end{array}$ \\
\hline & labor market. & Positive & $\begin{array}{l}\text { Expansion of opportunities for self-employment, search for remote } \\
\text { work, development and self-realization of highly qualified } \\
\text { specialists. }\end{array}$ \\
\hline $\begin{array}{l}\text { Expansion of } \\
\text { international } \\
\text { cooperation in the field } \\
\text { of R\&D }\end{array}$ & $\begin{array}{l}\text { The system of higher } \\
\text { and continuing } \\
\text { professional education }\end{array}$ & positive. & $\begin{array}{l}\text { Opportunities for wider international cooperation between } \\
\text { universities, institutions of higher education and vocational } \\
\text { education }\end{array}$ \\
\hline \multirow{2}{*}{ 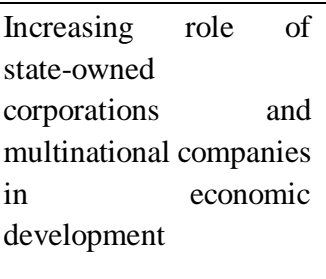 } & $\begin{array}{l}\text { Innovative } \\
\text { infrastructure }\end{array}$ & negative & $\begin{array}{l}\text { Decrease in demand for innovative institutions supporting small and } \\
\text { medium-sized venture businesses }\end{array}$ \\
\hline & $\begin{array}{l}\text { innovation activity of } \\
\text { organizations }\end{array}$ & Positive & $\begin{array}{l}\text { Large companies will begin to buy up the assets of bankrupt small } \\
\text { companies and expand; to ensure integration, new technological } \\
\text { solutions and incentives to strengthen the innovative activity of } \\
\text { companies will be required. }\end{array}$ \\
\hline \multirow{3}{*}{$\begin{array}{l}\text { An increase in the share } \\
\text { of the costs of the State } \\
\text { Budget of the Russian } \\
\text { Federation and regional } \\
\text { budgets for combating } \\
\text { the COVID-19 } \\
\text { pandemic and } \\
\text { eliminating its } \\
\text { consequences }\end{array}$} & $\begin{array}{l}\text { the innovation } \\
\text { infrastructure }\end{array}$ & negative & $\begin{array}{l}\text { Budget cuts in the development of innovative institutions, research } \\
\text { in the regions }\end{array}$ \\
\hline & & positive & $\begin{array}{l}\text { Significant increase in health care costs and research in the field of } \\
\text { medicine and pharmacology }\end{array}$ \\
\hline & $\begin{array}{l}\text { The innovative } \\
\text { activities } \\
\text { organizations }\end{array}$ & negative & $\begin{array}{l}\text { Since most of the budget will be spent on social needs, the risk of } \\
\text { budget cuts to support the innovative activity of enterprises in the } \\
\text { real sector of the economy and research and development increases }\end{array}$ \\
\hline \multirow{3}{*}{$\begin{array}{l}\text { Big leap in information } \\
\text { technologies, } \\
\text { telecommunications, } \\
\text { robotics, medicine and } \\
\text { pharmacology }\end{array}$} & $\begin{array}{l}\text { Innovative } \\
\text { infrastructure }\end{array}$ & positive & $\begin{array}{l}\text { Private and state investors will need to actively develop R\&D } \\
\text { infrastructure in the field of information and telecommunication } \\
\text { technologies, robotics, pharmacology and medicine }\end{array}$ \\
\hline & $\begin{array}{l}\text { innovation activity of } \\
\text { organizations }\end{array}$ & Positive & $\begin{array}{l}\text { The growth of private investment in modernization and the creation } \\
\text { of new technological high-tech solutions in these priority areas. }\end{array}$ \\
\hline & $\begin{array}{l}\text { The system of higher } \\
\text { and additional } \\
\text { professional education. }\end{array}$ & positive & $\begin{array}{l}\text { State and private educational organizations will be forced to } \\
\text { significantly update and improve the quality of educational } \\
\text { programs and scientific research. }\end{array}$ \\
\hline \multirow{3}{*}{$\begin{array}{l}\text { The need for progressive } \\
\text { structural changes in the } \\
\text { national economy, } \\
\text { increasing its } \\
\text { self-sufficiency } \\
\text { industries, knowledge } \\
\text { economy }\end{array}$} & $\begin{array}{l}\text { Innovative } \\
\text { infrastructure }\end{array}$ & positive & $\begin{array}{l}\text { The development of innovative infrastructure in the region, } \\
\text { supporting high-tech industries, knowledge economy }\end{array}$ \\
\hline & $\begin{array}{l}\text { innovation activity of } \\
\text { organizations }\end{array}$ & Positive & $\begin{array}{l}\text { Expansion of production within the framework of import } \\
\text { substitution programs, which requires new technological solutions, } \\
\text { highly qualified personnel, their training }\end{array}$ \\
\hline & The labor market. & Positive & $\begin{array}{l}\text { Creation of new modern jobs in high-tech activities, in the sectors of } \\
\text { the knowledge economy, online businesses, the growth of labor } \\
\text { productivity of workers. }\end{array}$ \\
\hline $\begin{array}{l}\text { Mass layoffs of workers } \\
\text { due to closure of } \\
\text { organizations and } \\
\text { downsizing }\end{array}$ & The labor market & negative & $\begin{array}{l}\text { The growth of shadow employment, increased migration to } \\
\text { labor-surplus regions of the country, a significant drop in solvent } \\
\text { demand, increased poverty, criminogenic environment, crime, risks } \\
\text { of socio-political conflicts }\end{array}$ \\
\hline
\end{tabular}




\section{Conclusion}

1). The strategic decisions of the state, large state corporations, multinational corporations, financial institutions can have a decisive influence on the consequences of the influence of modern trends on the intellectual capital of the country and its regions (positive or negative) in the post-economy.

2). The period of the pandemic and after it is fraught with significant risks for the erosion, development and increase of the effectiveness of the intellectual capital of the regions of the country.

3). The intellectual capital of countries and regions will be significantly affected by the main changes that will occur in the areas of international exchange not only of goods and services, but also of people and ideas.

4). In the service sector, there is a growing trend towards the digitalization of most services, which lead to a tremendous growth in the segment of telecommunications and online commerce and entertainment companies, that is, serious structural changes in the economy and employment.

5). Technological, economic and social realities of the pandemic period revealed new opportunities:

- Positive structural changes in the economy in favor of the knowledge economy, high-tech industries;

- Accelerate the development and implementation of innovations;

- Growth of labor productivity;

- Increase the personnel potential of the region;

- Expanding the boundaries of the labor market;

- New forms of employment and organizational structures.

All this can serve as a driver for the growth of intellectual capital in the regions and the country as a whole, and new knowledge and high-tech developments will help overcome the crisis and restore the international economy.

\section{Acknowledgements}

The work is performed according to the Russian Government Program of Competitive Growth of Kazan Federal University.

\section{References}

A New Balance: How the World Economy Will Change After a Pandemic. (2020). Russian Business consulting. Retrieved from https://www.rbc.ru/opinions/finances/07/04/2020/5e8b438b9a7947038b71b8d9

Bloomberg estimates the loss of the global economy. (2020). Russian Business consulting. Retrieved from https://www.rbc.ru/economics/09/04/2020/5e8ec97f9a79478537a44e47

Challenges and Opportunities in the Post-COVID-19 World. (2020). World Economic Forum insight report. Retrieved from http://www3.weforum.org/docs/WEF_Challenges_and_Opportunities_Post_COVID_19.pdf

Chen, J., Zhu, Z., \& Xie, H. Y. (2004). Measuring intellectual capital: a new model and empirical study. Journal of Intellectual Capital, 5(1), 196-212.

European Centre for Disease Prevention and Control. (2020). Retrieved from https://www.ecdc.europa.eu/en/publications-data/download-todays-data-geographic-distribution-covid-19-cases -worldwide

Gataullin, I. (2018). Individual profile of intellectual capital as an instrument of intangible assets management.

IDC says China's ICT Market Faces Both Opportunities and Challenges amid the COVID-19 Outbreak. (2020). International Data Corporation. Retrieved from https://www.idc.com/getdoc.jsp?containerId=prCHE46045120

Leliaert, Ph., Candries, W., \& Tilmans, R. (2003). Identifying and managing IC: a new classification. Journal of Intellectual Capital, 4(2), 202-214.

Leontyeva, L. S., \& Orlova, L. N. (2015). Management of intellectual capital: a textbook and a workshop for undergraduate and graduate programs. Moscow: Yurayt. 295:9:158.

Schwartz, P. (2012). The art of the long view: planning for the future in an uncertain world. Currency.

The economy of wartime. (2020). How the 2020 pandemic will change the world. Russian Business consulting. Retrieved from https://www.forbes.ru/biznes/395899-ekonomika-voennogo-vremeni-kak-pandemiya-2020-goda-izmenit-mir 
Trade set to plunge as COVID-19 pandemic upends global economy. (2020). World trade organization. Retrieved from https://www.wto.org/english/news_e/pres20_e/pr855_e.htm

Van Notten, P. (2006). Scenario development: a typology of approaches.

WHO warns of threat of "destructive" second wave of coronavirus. (2020). Ria news. Retrieved from https://ria.ru/20200603/1572388257.html

\section{Copyrights}

Copyright for this article is retained by the author(s), with first publication rights granted to the journal.

This is an open-access article distributed under the terms and conditions of the Creative Commons Attribution license (http://creativecommons.org/licenses/by/4.0/). 